\title{
"The influence of servant leadership on job satisfaction with individual character as a moderating variable"
}

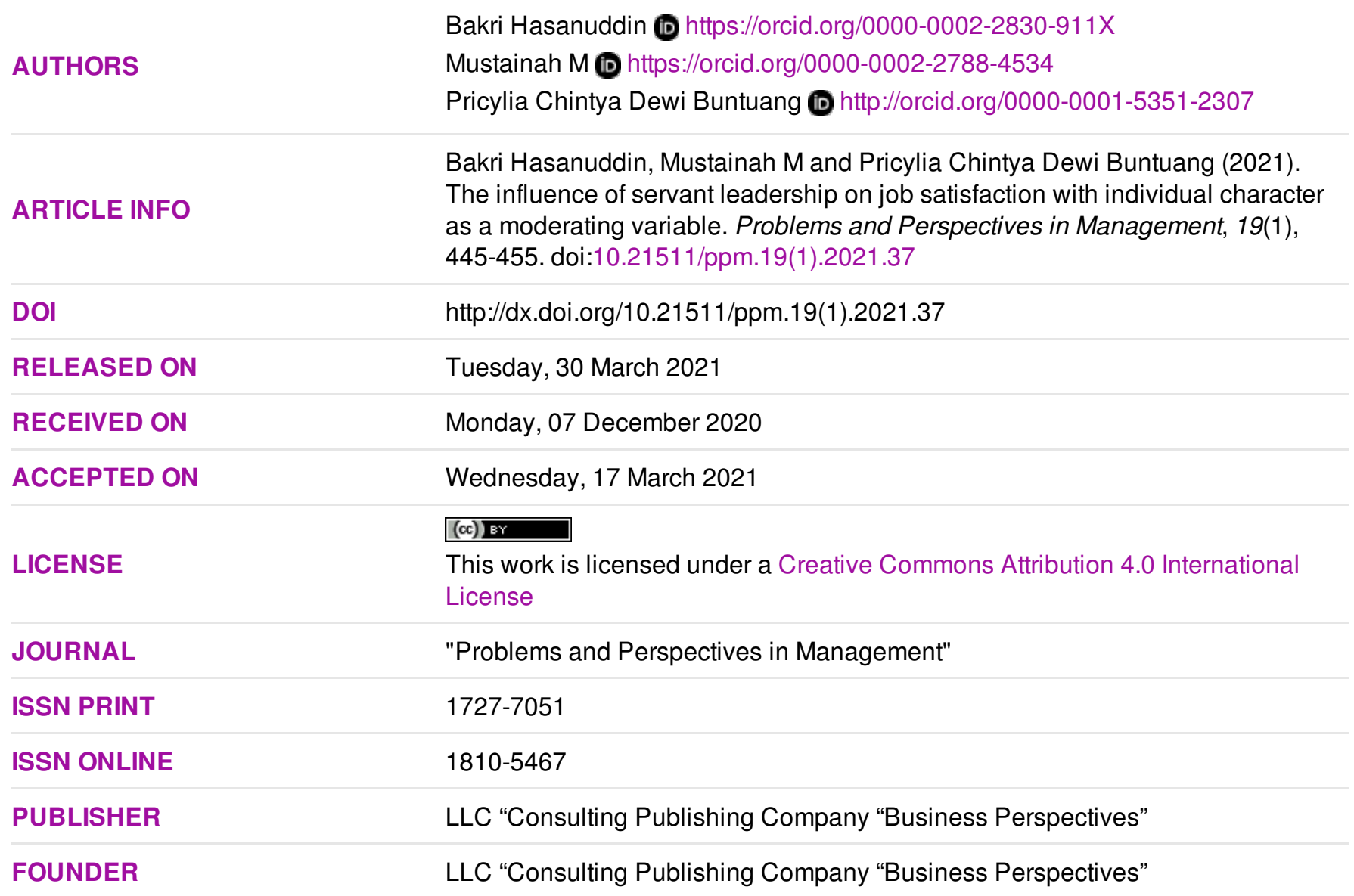

NUMBER OF REFERENCES

51

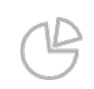

NUMBER OF FIGURES

1
=:-:

NUMBER OF TABLES

8

(C) The author(s) 2021. This publication is an open access article. 


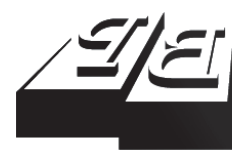

BUSINESS PERSPECTIVES

(O)

LLC "CPC "Business Perspectives" Hryhorii Skovoroda lane, 10, Sumy, 40022, Ukraine www.businessperspectives.org
Received on: $7^{\text {th }}$ of December, 2020 Accepted on: 17th of March, 2021 Published on: $30^{\text {th }}$ of March, 2021

() Bakri Hasanuddin, Mustainah M., Pricylia Chintya Dewi Buntuang, 2021

Bakri Hasanuddin, Dr., Associate Professor, Department of Management, Faculty of Economics and Business, Tadulako University, Palu, Indonesia. (Corresponding author)

Mustainah M., Dr., Associate Professor, Department of Public Administration, Faculty of Social and Political Science, Tadulako University, Palu, Indonesia.

Pricylia Chintya Dewi Buntuang, M.Sc., Lecturer, Department of Management, Faculty of Economics and Business, Tadulako University, Palu, Indonesia.
This is an Open Access article, distributed under the terms of the Creative Commons Attribution 4.0 International license, which permits unrestricted re-use, distribution, and reproduction in any medium, provided the original work is properly cited.

Conflict of interest statement: Author(s) reported no conflict of interest
Bakri Hasanuddin (Indonesia), Mustainah M. (Indonesia),

Pricylia Chintya Dewi Buntuang (Indonesia)

\section{THE INFLUENCE OF SERVANT LEADERSHIP ON JOB SATISFACTION WITH INDIVIDUAL CHARACTER AS A MODERATING VARIABLE}

\begin{abstract}
This study aims to investigate the influence of servant leadership on job satisfaction with individual character as a moderating variable. It used a quantitative approach with multiple linear regression analysis. The population of this study were employees of the Central Sulawesi province industry and trade office. It involved 72 samples selected using a purposive sampling technique. The results showed that servant leadership significantly influence job satisfaction with a value of $82.5 \%$. The most significant factor affecting job satisfaction is wisdom (correlation coefficient $=0.863$ ) in which the higher the wisdom, the higher the job satisfaction. The next factor is persuasive mapping in which the higher the persuasive mapping, the higher the job satisfaction (correlation coefficient $=0.697$ ). Then, it was followed by altruistic calling with the correlation coefficient value of 0.524 in which the higher the altruistic calling, the higher the job satisfaction. The last is emotional healing with a correlation coefficient value of 0.291 in which the higher the emotional healing, the higher the job satisfaction. On the other hand, organizational stewardship is the only factor does not influence the job satisfaction (correlation coefficient $=0.009$ )
\end{abstract}

\section{Keywords} service characteristics, employees, government, leaders, organizations

JEL Classification J81, L20

\section{INTRODUCTION}

Job satisfaction is the employees' perception of how well their work provides them with important things. Job satisfaction is considered as the result of individual assessment towards job achievement, working environment and life (Mahdavi \& Fazlollahtabar, 2011). The most important thing in job satisfaction is the attention of the leader because it will increase productivity or organizational performance (Mamiseishvili \& Rosser, 2011; Nasir et al., 2011). Therefore, an employee's job satisfaction is crucial for an organization or company (Côté et al., 2020), as it significantly influence with the productivity of organization (Bhatti \& Qureshi, 2007; Ghasemizad et al., 2012).

An organization member or employee with a high level of job satisfaction typically has a low level of leave and attendance, but usually commitment that makes them productive (Aziri, 2011; Shrivastava \& Purang, 2009). Discussing job satisfaction has always been fundamental and important for the organization because if there is a problem related to employees' job satisfaction, then it will affect the overall performance of the organization. Therefore, it has prompted some organizations to prioritize the issue of job satisfaction (Bhatti \& Qureshi, 
2007; Daryanto, 2014; Li et al., 2012). Then, concerning the vertical relationship between superiors and subordinates, it can be said that the leader's behavior, both positive and negative, will highly affect employee job satisfaction (I. Dugguh \& Dennis, 2014). Besides, job satisfaction is influence by unique characteristics of individuals. In this case, it can be influenced by age, gender, education, salary, and tenure, especially in the Industry and Trade Office of Central Sulawesi Province. Individual characteristics that influence job satisfaction include gender, education, and tenure (Hodson, 1984; Nasir, Fatimah, Mohammadi, Wan Shahrazad, et al., 2011). In this study, leadership style refers to the servant leadership style. The current demand for changes to the public bureaucracy in Indonesia is "serving" not being served. This leadership style will increase job satisfaction of the government employees, which, in turn, can be expected to provide satisfactory services to the community.

\section{LITERATURE REVIEW AND HYPOTHESES}

Job satisfaction is a complex variable highly influenced by the work environment, compensation and commitment, and leadership style (Mathis \& Jackson, 2006). Job satisfaction has five main aspects. The five aspects are the nature of the job, the compensation and benefits, the attitude of the leadership and job appraisers, the relationship with colleagues, and the opportunity to get a promotion (Aziri, 2011). Leadership has a major influence on job satisfaction, which will directly affect their work behavior (Adiguzel et al., 2020; Chiniara \& Bentein, 2016; Hunter et al., 2013; Neubert et al., 2016; Steel et al., 2017).

Servant leadership is a leadership model that prioritizes services provided to other parties, both horizontally (to fellow leaders) and vertically (to employees, customers, and community). The success of an organization is strongly influenced by the leadership style. Greenleaf (2019) proposes servant leadership as a leadership concept and model that prioritizes services provided for other parties, both horizontally (to fellow leaders) and vertically (to employees, customers, and the community). Furthermore, servant leadership highly emphasizes improving service performance and provides space subordinates in the decision making process that are deemed important to get employees' aspirations (Shahzad et al., 2013). Leadership practice is characterized by the increase of intention to serve others through various approaches which involve all parties.

Servant leadership also combines some important points, namely self-empowerment of employees, overall quality of employees, the team works, work participatory management, and ethics in each service as it becomes a separate philosophy for leadership (Page \& Wong, 2000; Lanctot \& Irving, 2007). In the concept of servant leadership, subordinates are given responsibilities for their works to make them develop which finally can lead to job satisfaction. (Drury, 2004).

Servant leaders enhance followers' self-efficacy and meaning through empowerment as one of the keys to make employees accomplished job satisfaction levels (Cheng et al., 2020; Erkutlu \& Chafra, 2015; Stouten \& Liden, 2020; van Dierendonck et al., 2014). Choosing the right leadership style will result in a high job satisfaction level (Akdol \& Arikboga, 2015; Kim et al., 2020; Luu, 2019; Sun \& Xia, 2018). Generally, servant leadership has a positive relation with job satisfaction (Drury, 2004). Stated servant leadership has a positive relationship with job satisfaction, more specifically on intrinsic and extrinsic job satisfaction (McCann et al., 2014). Besides, it is explained that servant leadership has a positive correlation and relationship with job satisfaction (Farrington \& Lillah, 2019).

Job satisfaction is a feeling or situation that is pleasant or positive about the work. Job satisfaction describes to what extent a person feels comfortable and satisfied with his/her job (Ali, 2016). The satisfaction and dissatisfaction of employees with their job will determine the subjectivity of their perspective on their work (Hajdukova et al., 2015). Employees express job satisfaction through attitudes, and in this case, the attitude refers to attitudes in building relationships and cooperation, interpreting subjects and phenomena in work, and events occurring in the workplace to personality (Hajdukova et al., 2015). 


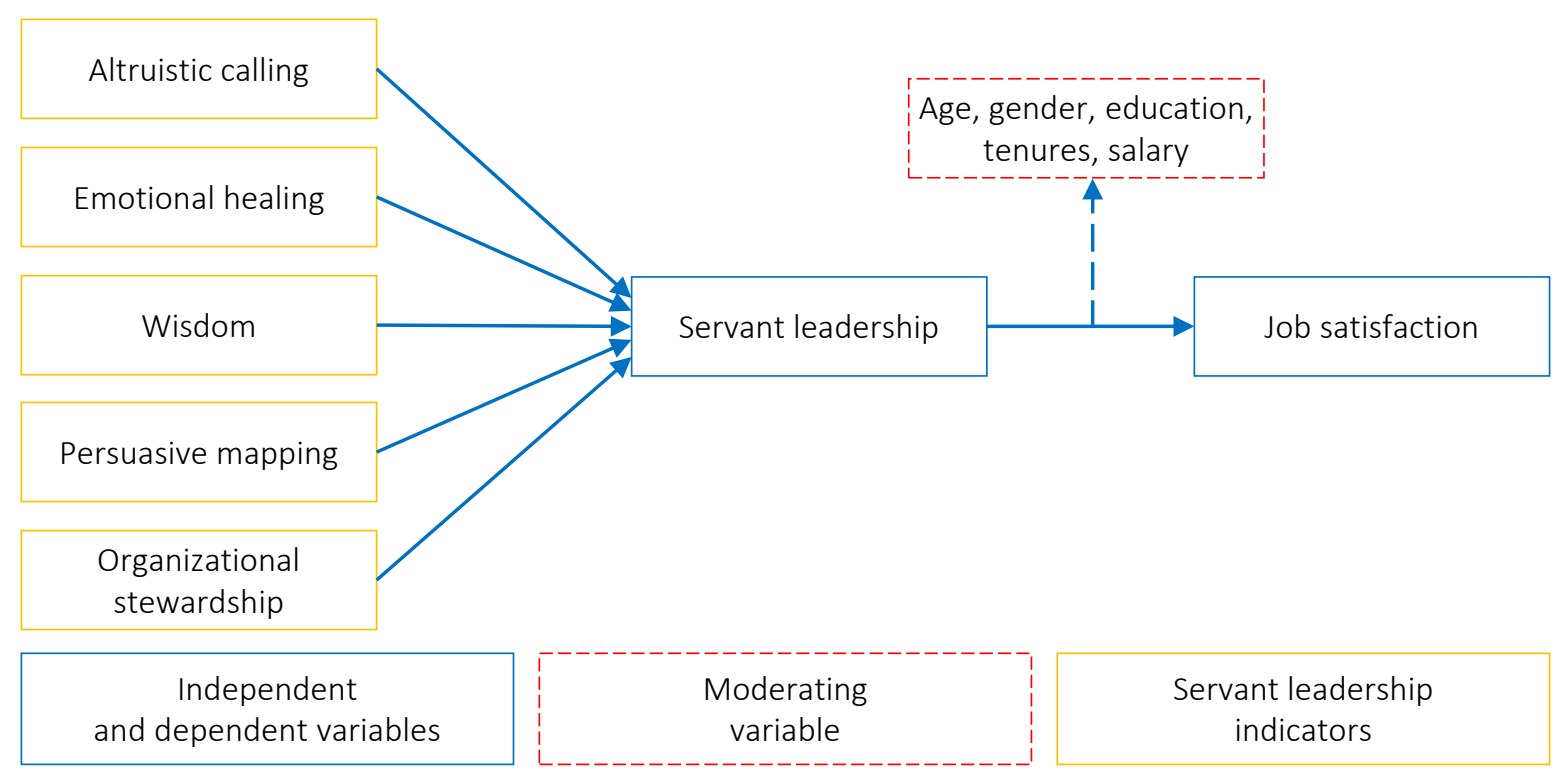

Figure 1. Research conceptual framework

Servant leadership developed by Patterson includes Agapao love, humility, altruism, vision, trust, empowerment, and service. This model explains that servant leadership shows the attitudes, beliefs, and behavior of the leader. Leaders who are oriented to these seven variables will automatically create satisfaction for their followers in carrying out their duties. Servant leadership style will more easily gain the trust of employees towards their leaders, which in turn will lead to employee loyalty and job satisfaction (Winston, 2003).

Previous research has emphasized the first principle of servant leadership (Barbuto \& Wheeler, 2006). This literature review explains the theory of servant leadership to develop understanding and guide the study. Conceptually, based on factorial analysis, servant leadership can be seen from 5 factors that are generated from 11 characteristics that empirically shows differences, namely, altruistic calling, emotional healing, wisdom, persuasive mapping, and organizational stewardship (Barbuto \& Wheeler, 2006). There are many stages or consideration in assessing leadership (Hansbrough et al., 2020).

By referring to Barbuto and Wheeler (2016), the independent variable of this study used five factors of servant leadership and the dependent variable was job satisfaction with individual characteristics as moderating variables (such as age, gen- der, education, salary, and tenure at the Industry and Trade Office of Central Sulawesi Province).

\subsection{Research conceptual framework}

Five-factor servant leadership (i.e., altruistic calling, emotional healing, persuasive mapping, wisdom, and organizational stewardship) and job satisfaction were set as independent and dependent variables. Moreover, in this study, individual characteristics, including age, gender, education level, tenure, and salary, are set as moderating variables by proposing a hypothesis that servant leadership in the Industry and Trade Office of Central Sulawesi Province has been appropriate; there is a significant effect of altruistic calls on job satisfaction; there is a significant effect of emotional healing on job satisfaction; there is a significant effect of wisdom on job satisfaction; there is a significant effect of persuasive mapping on job satisfaction; there is a significant effect of organizational stewardship on job satisfaction; there is an effect of individual characteristics on servant leadership and job satisfaction. This can be seen more clearly in Figure 1, which shows the conceptual framework.

\subsection{Research hypotheses}

- The level of servant leadership in the Industry and Trade Office in Central Sulawesi Province is appropriate. 
- Altruistic calling significantly affects job satisfaction.

- Emotional healing significantly affects job satisfaction.

- Wisdom significantly affects job satisfaction.

- Persuasive mapping significantly affects job satisfaction.

- Organizational stewardship significantly affects job satisfaction.

- Individual characteristics has relation and influences servant leadership and job satisfaction.

\section{RESEARCH METHOD}

The population of this study was 72 employees from the Industry and Trade Office of Central Sulawesi Province (implementing staff who did not occupy structural positions). The data were collected through a questionnaire containing statements related to servant leadership variables, individual characteristics, and job satisfaction. Specifically, the servant leadership variable in the questionnaire was based on Barbuto and Wheeler's questionnaire, which has been adjusted to the field conditions. The questionnaire has been tested for its validity and reliability. Hypotheses were examined using inferential statistics through SPSS software. The Kolmogorov-Smirnov test was used to check the data normality. The KolmogorovSmirnov statistical hypotheses are as follows:

\section{$H_{0}: \quad$ Data are distributed normally.}

\section{$H_{1}$ : Data are not distributed normally.}

Based on Table 1, the significance level of all variables is higher than 0.05 , then $\mathrm{H}_{0}$ is supported, meaning that the data are normally distributed.

\section{RESULTS}

Table 2 shows that out of 72 samples examined, some variables have a relatively high standard deviation, but the data distribution is normal.

\subsection{Hypothesis testing}

It seems that the level of the servant leadership style at the Industry and Trade Office in Central Sulawesi Province is appropriate. The suggested hypotheses are as follows:

- The level of servant leadership style is more than 70 .

Table 1. Kolmogorov-Smirnov test results

Source: Processed data.

\begin{tabular}{|c|c|c|c|c|}
\hline Variables & $\mathbf{N}$ & Kolmogorov-Smirnov Z & Sig. & Hypothesis \\
\hline Altruistic calling & 72 & 1.268 & .080 & $\mathrm{H}_{0}$ \\
\hline Emotional healing & 72 & 1.283 & .074 & $\mathrm{H}_{0}$ \\
\hline Wisdom & 72 & 1.280 & .076 & $\mathrm{H}_{0}$ \\
\hline Persuasive mapping & 72 & 1.239 & .093 & $\mathrm{H}_{0}$ \\
\hline Organizational healing & 72 & 1.304 & .067 & $\mathrm{H}_{0}$ \\
\hline Job satisfaction & 72 & 1.288 & .072 & $\mathrm{H}_{0}$ \\
\hline Servant leadership & 72 & 0.613 & .847 & $\mathrm{H}_{0}$ \\
\hline
\end{tabular}

Table 2. Descriptive statistics of research variables

Source: Processed data.

\begin{tabular}{|c|c|c|c|c|c|c|}
\hline Variables & $\mathbf{N}$ & $\begin{array}{c}\text { Number of related } \\
\text { questions }\end{array}$ & Mean value & Standard deviation & Minimum & Maximum \\
\hline Altruistic calling & 72 & 4 & 13.92 & 1.70 & 11.00 & 17.00 \\
\hline Emotional healing & 72 & 4 & 14.14 & 1.89 & 9.00 & 19.00 \\
\hline Wisdom & 72 & 5 & 15.83 & 3.46 & 11.00 & 24.00 \\
\hline Persuasive mapping & 72 & 5 & 17.06 & 4.13 & 8.00 & 24.00 \\
\hline Organizational healing & 72 & 5 & 19.31 & 3.12 & 13.00 & 24.00 \\
\hline Servant leadership & 72 & 23 & 80.25 & 8.99 & 57.00 & 100.00 \\
\hline Job satisfaction & 72 & 12 & 38.44 & 8.76 & 27.00 & 53,00 \\
\hline
\end{tabular}


- The level of servant leadership style is less than 70 .

To investigate the hypotheses, respondents' perceptions were analyzed of the ongoing servant leadership style at the Industry and Trade Office in Central Sulawesi Province. Ideally, the average servant leadership value is 115 given by each respondent, with a value for each item statement with a number of $5(23 \times 5=115)$ or $23 \times 5 \times 72$ $=8280$. The total score given by the respondent reached 5,778. Thus, the level of servant leadership in this government office was 5,778/8,280 $=0.70$ or 70 (absolute value). The score was compared by using a one-sample T-test with a significance level of $p<0.05$ and a mean value of 80.25. The results indicate that the mean value is higher than 70. Therefore, it could be said that the servant leadership style is appropriate by the probability of more than 95\% with the level of servant leadership style higher than 70 . Hence, the first hypothesis is supported in which the servant leadership style is appropriate.

Table 3. Simple sample T-test results

Source: Processed data.

\begin{tabular}{c|c:c}
\hline Variable & $\mathbf{T}$ & Significance level \\
\hline Servant leadership & 75.723 & .000 \\
\hline
\end{tabular}

As a descriptive-verificative study with quantitative variables, the hypotheses were tested through the Pearson correlation test. Statistical hypotheses of the Pearson correlation test are as follows:

\section{$H_{0}: \quad$ There is a significant relationship between independent and dependent variables.}

$H_{1}: \quad$ There is no significant relationship between
independent and dependent variables.

The significance level of this test for all hypotheses was less than 0.05 , indicating a significant correlation between servant leadership (i.e. altruistic calling, emotional healing, persuasive mapping, wisdom, and organizational stewardship) and job satisfaction. The correlation coefficients consisted of positive values, so it could be said that the higher the independent variables, the higher the dependent variables.
Table 4. Pearson correlation coefficient results

Source: Processed data.

\begin{tabular}{|c|c|c|c|}
\hline \multirow{2}{*}{\multicolumn{2}{|c|}{$\begin{array}{c}\text { Independent } \\
\text { variable }\end{array}$}} & $\begin{array}{c}\text { Dependent } \\
\text { variable }\end{array}$ & \multirow[t]{2}{*}{ Hypothesis } \\
\hline & & \multirow{2}{*}{$\begin{array}{c}\text { Job satisfaction } \\
\begin{array}{c}\text { Correlation } \\
\text { coefficient }\end{array}\end{array}$} & \\
\hline \multirow{3}{*}{$\begin{array}{l}\text { Servant } \\
\text { leadership }\end{array}$} & .815 & & \multirow{3}{*}{$H_{0}$} \\
\hline & .000 & Sig ( $P$-value) & \\
\hline & 72 & Sample size & \\
\hline \multirow{3}{*}{$\begin{array}{l}\text { Altruistic } \\
\text { calling }\end{array}$} & .524 & $\begin{array}{l}\text { Correlation } \\
\text { coefficient }\end{array}$ & \multirow{3}{*}{$H_{0}$} \\
\hline & .000 & Sig ( $P$-value) & \\
\hline & 72 & Sample size & \\
\hline \multirow{3}{*}{$\begin{array}{l}\text { Emotional } \\
\text { healing }\end{array}$} & .291 & $\begin{array}{l}\text { Correlation } \\
\text { coefficient }\end{array}$ & \multirow{3}{*}{$H_{0}$} \\
\hline & .013 & Sig ( $P$-value) & \\
\hline & 72 & Sample size & \\
\hline \multirow{3}{*}{ Wisdom } & .863 & $\begin{array}{c}\text { Correlation } \\
\text { coefficient }\end{array}$ & \multirow{3}{*}{$H_{0}$} \\
\hline & .000 & Sig ( $P$-value) & \\
\hline & 72 & Sample size & \\
\hline \multirow{3}{*}{$\begin{array}{l}\text { Persuasive } \\
\text { mapping }\end{array}$} & .697 & $\begin{array}{l}\text { Correlation } \\
\text { coefficient }\end{array}$ & \multirow{3}{*}{$H_{0}$} \\
\hline & .000 & Sig ( $P$-value) & \\
\hline & 72 & Sample size & \\
\hline \multirow{3}{*}{$\begin{array}{l}\text { Organizational } \\
\text { healing }\end{array}$} & .009 & $\begin{array}{l}\text { Correlation } \\
\text { coefficient }\end{array}$ & \multirow{3}{*}{$H_{1}$} \\
\hline & 938 & Sig ( $P$-value) & \\
\hline & 72 & Sample size & \\
\hline
\end{tabular}

Furthermore, this study used multiple regression analysis to determine the effect of servant leadership factor (altruistic calling, emotional healing, persuasive mapping, wisdom, organizational stewardship) as independent variables and job satisfaction as the dependent variable. The results are shown in Table 5.

Table 5. Statistics of multiple regression of job satisfaction

\begin{tabular}{c|c|c|c}
\hline $\boldsymbol{R}$ & $\boldsymbol{R}$ Square & $\begin{array}{c}\text { Adjusted } \boldsymbol{R} \\
\text { Square }\end{array}$ & $\begin{array}{c}\text { Std. error of the } \\
\text { estimate }\end{array}$ \\
\hline .915 & .837 & .825 & 3.665 \\
\hline
\end{tabular}

Table 5 shows the influence of servant leadership on job satisfaction (0.825). This means that $82.5 \%$ of job satisfaction is influenced by servant leadership, and the rest is influenced by other variables not examined in this study. In general, the multiple linear regression used Adjusted $R$ Square, since it is more permanent even though the independent variable increases. Based on Table 5, the multiple correlation coefficient reaches 0.915 with the coefficient determination of 0.837 and the standard deviation of 3.665 . 
Table 6 presents a significant simultaneous effect of servant leadership on job satisfaction based on the calculated $F$-values.

Table 6. Variance of multiple regression of job satisfaction

Source: Processed data.

\begin{tabular}{l|c:c:c|c}
\hline \multicolumn{1}{c}{ Source } & $\begin{array}{c}\text { Sum of } \\
\text { squares }\end{array}$ & df & F & $\begin{array}{c}\text { Significance } \\
\text { level }\end{array}$ \\
\hline Regression effect & 4565.080 & 5 & 67.959 & .000 \\
\hline Residual & 886.698 & 66 & & \\
\hdashline Total & 5451.778 & 71 & & \\
\hline
\end{tabular}

Table 7 indicated that the existence of four out of five variables in the model was significant. Variables such as altruistic calling, emotional healing, wisdom, and persuasive mapping had a significant effect on dependent variables, while organizational stewardship had no significant effect as it had a linear relationship. Therefore, it was not considered in the regression model.

Table 7. Statistics related to retained independent variables in the regression model

Source: Processed data.

\begin{tabular}{|c|c|c|c|c|c|}
\hline \multirow{2}{*}{ Variables } & \multicolumn{2}{|c|}{$\begin{array}{l}\text { Unstandardized } \\
\text { coefficients }\end{array}$} & \multirow{2}{*}{$\frac{\begin{array}{c}\text { Standardized } \\
\text { coefficients }\end{array}}{\text { Beta }}$} & \multirow{2}{*}{$t$} & \multirow{2}{*}{ Sig. } \\
\hline & B & $\begin{array}{l}\text { Std. } \\
\text { error }\end{array}$ & & & \\
\hline (Constant) & -14.092 & 5.514 & & -2.556 & .013 \\
\hline $\begin{array}{l}\text { Altruistic } \\
\text { calling }\end{array}$ & .809 & .290 & .157 & 2.790 & .007 \\
\hline $\begin{array}{l}\text { Emotional } \\
\text { healing }\end{array}$ & .640 & .236 & .138 & 2.705 & .009 \\
\hline Wisdom & 1.499 & .171 & .591 & 8.776 & .000 \\
\hline $\begin{array}{l}\text { Persuasive } \\
\text { mapping }\end{array}$ & .625 & .134 & .294 & 4.651 & .000 \\
\hline
\end{tabular}

Individual characteristic has relation and influences servant leadership and job satisfaction.

ANOVA test was used to investigate whether the variables are equal or different in terms of respondents' individual characteristics and in different dimensions of the population. The statistical hypotheses of this test are as follows:

\section{$H_{0}$ : There is a significant difference between variables.}

$H_{1}$ : There is no significant difference between variables.
The result of the ANOVA test and using the significance level (more than 0.05) indicates that there is no significant difference between individual characteristics (i.e. age, gender, education, tenures, and salary) and servant leadership. Therefore, it can be said that by the probability of $95 \%$, Individual characteristic does not have relation and influence of servant leadership and job satisfaction, so the hypothesis is not supported.

The results of this study revealed that:

- By the probability of $95 \%$, the level of servant leadership at the Industry and Trade Office of Central Sulawesi Province showed a mean value of 80.25 with a significant level of 0.000. It is higher than the average level (70) by using a one-sample T-test. The experimental mean value is higher than the theoretical one meaning that respondents' perception about servant leadership is appropriate. Therefore, the first hypothesis is supported.

- By the probability of $95 \%$, servant leadership has a significant relation with job satisfaction with a correlation coefficient of 0.815 and significant value of 0.000 .

- By the probability of $95 \%$, altruistic calling has a significant relation with job satisfaction with a correlation coefficient of 0.524 and significant value of 0.000

- By the probability of 95\%, emotional healing has a significant relation with job satisfaction with a correlation coefficient of 0.291 and significant value of 0.013

- By the probability of $95 \%$, wisdom has a significant relation with job satisfaction with a correlation coefficient of 0.863 and significant value of 0.000

- By the probability of $95 \%$, persuasive mapping has a significant relation with job satisfaction with a correlation coefficient of 0.697 and significant value of 0.000

By the probability of $95 \%$, organizational stewardship has a significant relation with 
Table 8. ANOVA test results

Source: Processed data.

\begin{tabular}{|c|c|c|c|c|c|}
\hline Variable & Component & $\mathbf{F}$ & $\begin{array}{c}\text { Significance } \\
\text { level }\end{array}$ & Result & Level \\
\hline \multirow[b]{5}{*}{$\begin{array}{l}\text { Servant } \\
\text { leadership }\end{array}$} & Age & 2.680 & .121 & Zero Hypothesis is not supported & $30-34,35-39,40-44,45-49$, more than 50. \\
\hline & Gender & 3.770 & .093 & Zero Hypothesis is not supported & Male, Female \\
\hline & Education & 1.471 & .293 & Zero Hypothesis is not supported & Less than diploma, Bachelor, Master. \\
\hline & Tenures & 1.679 & .258 & Zero Hypothesis is not supported & $5-9,10-14,15-19,20-24$, more than 25 \\
\hline & Salary & 2.719 & .118 & Zero Hypothesis is not supported & $\begin{array}{l}\text { In million rupiahs: } \\
2.535 .375-2.904 .693 \\
2.904 .695-3.274 .013 \\
3.274 .015-3.643 .333 \\
3.643 .335-4.012 .653 \\
4.012 .655-4.381 .973\end{array}$ \\
\hline
\end{tabular}

job satisfaction with a correlation coefficient of 0.009 and significant value of 0.938

- The result of multiple linear regression showed that servant leadership can explain the changes in job satisfaction of Industry and Trade Office of Central Sulawesi Province with a value of $82.5 \%$.

\section{DISCUSSION}

It is crucial to consider job satisfaction, especially in government organizations, since a high level of job satisfaction can create a conducive and pleasant work environment. Indeed, such an environment affects work performance because the interaction of staff with the environment can result in job satisfaction. In the current globalization era, job satisfaction is a crucial aspect to be considered, especially in Indonesia (Marzuki et al., 2012).

Generally, job satisfaction often causes problems in government agencies in Indonesia. However, the results of this study indicate that servant leadership has a significant effect on job satisfaction. This study was conducted in local government agencies in Indonesia, especially in Central Sulawesi Province. Overall, servant leadership affects job satisfaction, and it is in line with Hebert (2003). It shows a significant correlation between servant leadership and job satisfaction. The correlation coefficient consists of positive values meaning that the higher the independent variable, the higher the dependent variable. In this study, the factor that greatly influences job satisfaction is wisdom. The higher the wisdom, the higher the job satisfaction, while the altruistic calling be- comes the second factor. Finally, organizational management is the only independent variable that does not affect job satisfaction.

Servant leadership is required in all organizational activities, particularly for local governments whose orientation is to provide services to the community. Given the poor service quality in the local government agencies, a leader is required who has a vision of service, and it is not easy to get such a leader. It is not easy to be a leader and servant at the same time (Sendjaya \& Sarros, 2002). In this situation, servant leadership is highly needed because it combines several leadership models or can be called a comprehensive leadership model (Sendjaya et al., 2008). This means that servant leadership can be applied to all aspects, including changing employees' perceptions of job satisfaction. This is evidenced by the hypothesis of this study, which shows that servant leadership has a relationship with job satisfaction. Participatory leadership has a positive correlation with employee job satisfaction (Chan, 2019).

The relation between servant leadership with job satisfaction in organizations has been proven by previous studies (Horsman, 2002; Miears, 2004). Job satisfaction is an important theme for workers in organizations and even it is a very attractive topic to anyone who studies it (Lu et al., 2005). Servant leadership embraces all aspects of the organization, both internally and externally. In this case, government agencies in Central Sulawesi Province show a positive relationship between servant leadership and job satisfaction as indicated by altruistic calls, emotional healing, persuasive mapping, wisdom, and organizational management. It relates to employees, society as customers, 
and the community. Integrity and a willingness to serve are characteristics of servant leadership, which consists of employees, customers, and the community (Liden et al., 2008). Meanwhile, the leadership in regional agencies does not commonly show characteristics of servant leadership. This is reinforced by the definition that subordinates and leaders are said to be opposites (Spears, 2010). It means subordinates and leader are different as proven by this study, but in organization, leaders can gather with the subordinate even serve them.

Job satisfaction can be realized through servant leadership mediated by staff involvement. It indicates that the stronger the relation, the happier the staff. It means that employees enjoy a condu- cive work environment and leadership involvement. Job satisfaction can be realized if the staff highly perceived the principles of servant leadership (Laub, 1999). The results of previous studies indicate that employees' positive perceptions of servant leadership in organizations mean that the employees have a higher level of job satisfaction (Thompson, 2002). The results of this study are expected to have implications for government organizations in perceiving servant leadership as a job satisfaction value. Studies concerning servant leadership in local government agencies are still limited. Therefore, the results of this study are expected to contribute to researchers and organizations or governments to see the correlation between servant leadership and job satisfaction.

\section{CONCLUSION}

The results of this study show that wisdom has the most significant relation with job satisfaction in the Industry and Trade Office of Central Sulawesi Province. In other words, the higher the wisdom, the higher the job satisfaction. Then, it is followed by altruistic calling in which the higher the altruistic calling, the higher the job satisfaction. The next is emotional healing in which the higher the emotional healing, the higher the job satisfaction. Then, it is followed by persuasive mapping, in which the higher the persuasive mapping, the higher the job satisfaction. Leaders with high persuasive mapping can see the future of the organization, and act and encourage others to get involve. The organizational stewardship is the only variable with no significant relation with job satisfaction. Therefore, further studies are expected to understand more the perception of the staff on organizational stewardship. Based on this concept, it is important to encourage employees to be happier at work because servant leadership is more visible in its commitment to encourage the spirit of work.

\section{AUTHOR CONTRIBUTIONS}

Conceptualization: Bakri Hasanuddin.

Data curation: Bakri Hasanuddin.

Formal analysis: Bakri Hasanuddin.

Funding acquisition: Bakri Hasanuddin.

Investigation: Mustainah M.

Methodology: Mustainah M.

Project administration: Bakri Hasanuddin, Mustainah M.

Resources: Mustainah M, Pricylia Chintya Dewi Buntuang.

Software: Pricylia Chintya Dewi Buntuang.

Supervision: Pricylia Chintya Dewi Buntuang.

Validation: Pricylia Chintya Dewi Buntuang.

Visualization: Pricylia Chintya Dewi Buntuang.

Writing - original draft: Bakri Hasanuddin

Writing - review \& editing: Pricylia Chintya Dewi Buntuang. 


\section{REFERENCES}

1. Adiguzel, Z., Ozcinar, M. F., \& Karadal, H. (2020). Does servant leadership moderate the link between strategic human resource management on rule breaking and job satisfaction? European Research on Management and Business Economics, 26(2), 103 110. https://doi.org/10.1016/j. iedeen.2020.04.002

2. Akdol, B., \& Arikboga, F. S. (2015). The Effects of Leader Behavior on Job Satisfaction: A Research on Technology Fast50 Turkey Companies. Procedia - Social and Behavioral Sciences, 195, 278-282. https://doi.org/10.1016/j.sbspro.2015.06.159

3. Ali, W. (2016). Understanding the Concept of Job Satisfaction, Measurements, Theories and its Significance in the Recent Organizational Environment: A Theoretical Framework. Archives of Business Research, 4(1). https://doi. org/10.14738/abr.41.1735

4. Aziri, B. (2011). Job Satisfaction, a Literature Review. Management Research and Practice, 3(1), 77-90. Retrieved from http://mrp.ase.ro/ no34/f7.pdf

5. Barbuto, J. E., \& Wheeler, D. W. (2006). Scale development and construct clarification of servant leadership. Group and Organization Management, 31(3), 300-326. https://doi. org/10.1177/1059601106287091

6. Bhatti, K. K., \& Qureshi, T. M. (2007). International Review of Business Research Papers. Impact of Employee Participation on Job Satisfaction, Employee Commitment and Employee Productivity. Human Resource Management, 3(2), 54-68.

7. Chan, S. C. H. (2019). Participative leadership and job satisfaction: The mediating role of work engagement and the moderating role of fun experienced at work. Leadership \& Organization Development Journal, 40(3), 319333. https://doi.org/10.1108/LODJ06-2018-0215

8. Cheng, L., Guo, H., \& Lin, H. (2020). The influence of leadership behavior on miners' work safety

behavior. Safety Science, 132, 104986. https://doi.org/10.1016/j. ssci.2020.104986

9. Chiniara, M., \& Bentein, K. (2016). Linking servant leadership to individual performance: Differentiating the mediating role of autonomy, competence and relatedness need satisfaction. The Leadership Quarterly, 27(1), 124-141. https://doi.org/10.1016/j. leaqua.2015.08.004

10. Côté, K., Lauzier, M., \& Stinglhamber, F. (2020). The relationship between presenteeism and job satisfaction: A mediated moderation model using work engagement and perceived organizational support. European Management Journal. https://doi. org/10.1016/j.emj.2020.09.001

11. Daryanto, E. (2014). Individual Characteristics, Job Characteristics, and Career Development: A Study on Vocational School Teachers' Satisfaction in Indonesia. American Journal of Educational Research, 2(8), 698-702. https://doi. org/10.12691/education-2-8-20

12. Drury, S. (2004). Copy Limitations. March.

13. Dugguh, S., \& Dennis, A. (2014). Job satisfaction theories: Traceability to employee performance in organizations. IOSR Journal of Business and Management, 16(5), 11-18. https:// doi.org/10.9790/487x-16511118

14. Erkutlu, H., \& Chafra, J. (2015). The Effects of Empowerment Role Identity and Creative Role Identity on Servant Leadership and Employees' Innovation Implementation Behavior. Procedia - Social and Behavioral Sciences, 181, 3-11. https://doi. org/10.1016/j.sbspro.2015.04.860

15. Farrington, S. M., \& Lillah, R. (2019). Servant leadership and job satisfaction within private healthcare practices. Leadership in Health Services, 32(1), 148-168. https://doi.org/10.1108/LHS-092017-0056
16. Ghasemizad, A., Zadeh, M. A., \& Bagheri, S. (2012). A study of the relationship between teachers and principals ' spiritual leadership, quality of work life, job satisfaction and productivity. American Journal of Scientific Research, 49(49), 11-20.

17. Greenleaf, R. K. (2019). The Servant as Leader. Leadership, 407-415. https://doi.org/10.2307/j. ctvpg85tk.36

18. Hajdukova, A., Klementova, J., \& Klementova, J. (2015). The Job Satisfaction as a Regulator of the Working Behaviour. Procedia Social and Behavioral Sciences, 190, 471-476. https://doi.org/10.1016/j. sbspro.2015.05.028

19. Hansbrough, T. K., Lord, R. G., Schyns, B., Foti, R. J., Liden, R. C., \& Acton, B. P. (2020). Do you remember? Rater memory systems and leadership measurement. The Leadership Quarterly, 101455. https://doi. org/10.1016/j.leaqua.2020.101455

20. Hebert, S. C. (2003). The relationship of perceived servant leadership and job satisfaction from the follower's perspective. Capella University. Retrieved from https://olagroup.com/display. asp? page $=$ dissertations_theses

21. Hodson, R. (1984). A focus on employer characteristics. Sociology and Social Research, 69(1), 22-49.

22. Horsman, J. H. (2002). Perspectives of servant-leadership and spirit in organizations.

Dissertation Abstracts International, 62(03), 1119. (UMI No. 3010149). Retrieved from https://www.worldcat.org/title/ perspectives-of-servant-leadership-and-spirit-in-organizations/ oclc/50120171

23. Hunter, E. M., Neubert, M. J., Perry, S. J., Witt, L. A., Penney, L. M., \& Weinberger, E. (2013). Servant leaders inspire servant followers: Antecedents and outcomes for employees and the organization. The Leadership Quarterly, 24(2), 316-331. https://doi.org/10.1016/j. leaqua.2012.12.001 
24. Kim, M., Kim, Y. D., \& Lee, H.-W. (2020). It is time to consider athletes' well-being and performance satisfaction: The roles of authentic leadership and psychological capital. Sport Management Review, S1441352319300245. https://doi. org/10.1016/j.smr.2019.12.008

25. Lanctot, J. D., \& Irving, J. A. (2007). Character and Leadership: Situating Servant Leadership in a Proposed Virtues Framework. Leadership, 6(2007), 26.

26. Laub, J. A. (1999). Assessing the servant organization: Development of the servant organizational leadership assessment (SOLA) instrument. Florida Atlantic University, 0119.

27. Li, B., Urban, J. P. G., \& Yu, J. (2012). The distribution of fibrillin-2 and LTBP-2, and their co-localisation with fibrillin-1 in adult bovine tail disc Journal of Anatomy, 5811(Ii), 164-172. https://doi.org/10.1111/j.14697580.2011.01455.x

28. Liden, R. C., Wayne, S. J., Zhao, H., \& Henderson, D. (2008). Servant leadership: Development of a multidimensional measure and multi-level assessment. The Leadership Quarterly, 19(2), 161177. https://doi.org/10.1016/j. leaqua.2008.01.006

29. Lu, H., While, A. E., \& Louise Barriball, K. (2005). Job satisfaction among nurses: A literature review. International Journal of Nursing Studies, 42(2), 211-227. https://doi.org/10.1016/j. ijnurstu.2004.09.003

30. Luu, T. (2019). Relationship between benevolent leadership and the well-being among employees with disabilities. Journal of Business Research, 99, 282-294. https://doi.org/10.1016/j. jbusres.2019.03.004

31. Mahdavi, I., \& Fazlollahtabar, H. (2011). Design of a Fuzzy Job Satisfaction Matrix with Dynamic Performance Criteria (pp. 11731178).

32. Mamiseishvili, K., \& Rosser, V. J. (2011). Examining the Relationship between Faculty Productivity and Job Satisfaction (33 p.).
33. Marzuki, P. F., Permadi, H., \& Sunaryo, I. (2012). Factors Affecting Job Satisfaction of Workers in Indonesian Construction Companies. Journal of Civil Engineering and Management, 18(3), 299-309. https://doi.org/10.3846/13923730. 2012.698889

34. Mathis, R. L., \& Jackson, J. H. (2006). Human Resource Management Manajemen Sumber Daya Manusia (10th ed.). Salemba Empat, Jakarta.

35. McCann, J. T., Graves, D., \& Cox, L. (2014). Servant Leadership, Employee Satisfaction, and Organizational Performance in Rural Community Hospitals. International Journal of Business and Management, 9(10), 28. https://doi.org/10.5539/ijbm. v9n10p28

36. Miears, L. D. (2004). Servantleadership and job satisfaction: A correlational study in Texas Education Agency Region X public schools. Texas A\&M UniversityCommerce.

37. Nasir, R., Fatimah, O., Mohammadi, M. S., Wan Shahrazad, W. S., Khairudin, R., \& Halim, F. W. (2011). Demographic variables as moderators in the relationship between job satisfaction and task performance. Pertanika Journal of Social Science and Humanities, 19(SPEC. ISSUE), 33-40.

38. Nasir, R., Fatimah, O., Mohammadi, M. S., Wan, W. S., Shahrazad, \& Khairudin. (2011). Demographic Variables as Moderators in the Relationship between Job Satisfaction and Task Performance. Pertanika Journal of Social Science and Humanities, 19, 33-40. Retrieved from https:// www.researchgate.net/publication/287694102_Demographic_ variables_as_moderators_in_the_ relationship_between_job_satisfaction_and_task_performance

39. Neubert, M. J., Hunter, E. M., \& Tolentino, R. C. (2016). A servant leader and their stakeholders: When does organizational structure enhance a leader's influence? The Leadership
Quarterly, 27(6), 896-910. https://doi.org/10.1016/j. leaqua.2016.05.005

40. Page, D., \& Wong, T. (2000). A conceptual framework for measuring servant leadership. The Human Factor in Shaping the Course of History and Development, May, 69-110. Retrieved from http://www.drpaulwong.com/aconceptual-framework-for-measuring-servant-leadership/

41. Sendjaya, S., \& Sarros, J. C. (2002). Servant Leadership: Its Origin, Development, and Application in Organizations. Journal of Leadership \& Organizational Studies, 9(2), 57-64. https://doi. org/10.1177/107179190200900205

42. Sendjaya, S., Sarros, J. C., \& Santora, J. C. (2008). Defining and Measuring Servant Leadership Behaviour in Organizations: Servant Leadership Behaviour in Organizations. Journal of Management Studies, 45(2), 402-424. https://doi.org/10.1111/ j.1467-6486.2007.00761.x

43. Shahzad, A., Rizvi, R. A., Waheed, A., Khan, I., Usman, S. M., Nazir, N., Amin, G., \& Kiyani, T. M. (2013). Linking servant leadership with organizational citizenship behavior through trust: An embryonic structural modelling approach. European Journal of Social Sciences, 39(2), 273-284. Retrieved from https://citeseerx. ist.psu.edu/viewdoc/download?d oi $=10.1 .1 .1087 .4893 \&$ rep=rep $1 \&$ type $=$ pdf

44. Shrivastava, A., \& Purang, P. (2009). Employee Perceptions of Job Satisfaction: Comparative Study on Indian Banks. Asian Academy of Management Journal, 14(2), 65-78. Retrieved from http://eprints.usm.my/36412/1/ AAMJ_14.2.4.pdf

45. Spears, L. C. (2010). Character and servant leadership: Ten characteristics of effective, caring leaders. The Journal of Virtues \& Leadership, 1(1), 25-30. Retrieved from https://www.regent.edu/ acad/global/publications/jvl/ vol1_iss1/Spears_Final.pdf

46. Steel, B. S., Pierce, J. C., Berman, E., \& Taylor, J. (2017). Job 
satisfaction in Cascadia: A comparison of British Columbia, Oregon, and Washington civil servants. The Social Science Journal, 54(4), 379-388. https://doi. org/10.1016/j.soscij.2017.07.011

47. Stouten, J., \& Liden, R. C. (2020). Social Loafing in Organizational Work Groups: The Mitigating Effect of Servant Leadership. In Individual Motivation within Groups (pp. 55-80). Elsevier. https://doi.org/10.1016/B978-0 12-849867-5.00002-1

48. Sun, A., \& Xia, J. (2018). Teacherperceived distributed leadership, teacher self-efficacy and job satisfaction: A multilevel SEM approach using the 2013 TALIS data. International Journal of Educational Research, 92, 8697. https://doi.org/10.1016/j. ijer.2018.09.006

49. Thompson, R. S. (2002). The perception of servant leadership characteristics and job satisfaction in a church-related college (Doctoral dissertation). Available from ProQuest Dissertations \& Theses Database. (UMI No. 3103013).

50. van Dierendonck, D., Stam, D., Boersma, P., de Windt, N., \& Alke- ma, J. (2014). Same difference?

Exploring the differential mechanisms linking servant leadership and transformational leadership to follower outcomes. The Leadership Quarterly, 25(3), 544-562. https://doi. org/10.1016/j.leaqua.2013.11.014

51. Winston, B. E. (2003). Extending Patterson's Servant Leadership Model: Explaining How Leaders and Followers Interact in a Circular Model. Servant Leadership Research Roundtable, August, 1-9. 